\title{
Genetic identification of functions of TL-DNA transcripts in octopine crown galls
}

J. Leemans ${ }^{1}$, R. Deblaere' ${ }^{1}$ L. Willmitzer ${ }^{2}$, H. De Greve ${ }^{1}$, J.P. Hernalsteens ${ }^{1}$, M. Van Montagu ${ }^{1.3}$, and J. Schell ${ }^{2.3 *}$

${ }^{1}$ Laboratorium voor Genetische Virologie, Vrije Universiteit Brussel, B-1640 St.-Genesius-Rode, Belgium, 'Max-Planck-Institut für Züchtungsforschung, D-5000 Köln 30, FRG, and ' ${ }^{3}$ Laboratorium voor Genetica, Rijksuniversiteit Gent, B-9000 Gent, Belgium

Communicated by J. Schell

Received 8 January 1982

The TL-DNA in octopine crown galls encodes seven transcripts most, if not all, expressed from individual promoters. Site-specific deletions and substitutions in the T-region of the octopine plasmid pTiB6S3 indicate some of the functions of the TL-DNA transcripts. Two of the seven genes are sufficient to allow tumorous growth. T-DNA transfer and oncogenicity are controlled by different and independently acting functions. None of the transcripts of TLDNA appear to be essential for T-DNA transfer. Four, possibly five, of the TL-DNA transcripts act by suppressing organ development. Shoot and root formation are suppressed by the action of different transcripts.

Key words: Agrobacterium/Ti plasmids/site-specific mutagenesis/crown gall

\section{Introduction}

The accompanying paper by Willmitzer et al. gives a general introduction to the role of large $\mathrm{Ti}$ plasmids in the formation of crown gall plant tumors. The physical structure of the Ti plasmid T-DNA has been studied by DNA/DNA hybridizations (Lemmers et al., 1980; Thomashow et al., 1980a; De Beuckeleer et al., 1981) and by genomic cloning (Zambryski et al., 1980; Yadav et al., 1980; Thomashow et al., 1980b). The T-DNA in nopaline crown galls is colinear with a continuous fragment of $23 \mathrm{~kb}$ of the Ti plasmids of strains C58 and T37. It is often present in tandem repeats and is covalently linked to chromosomal plant DNA sequences (Zambryski et al., 1980).

The more complex organisation of the T-DNA in octopine crown galls may involve either one or of two fragments from neighbouring sequences on the Ti plasmid. All tumor lines investigated thus far contain the so-called TL fragments; in primary tumors and in some stable tumor lines the neighbouring TR fragment is found as an additional sequence (Thomashow et al., 1980a; De Beuckeleer et al., 1981, unpublished data).

There is extensive homology between the TL-DNA in octopine lines and a segment in the T-DNA of nopaline lines (Depicker et al., 1978; Chilton et al., 1978; Engler et al., 1981) and these conserved DNA sequences seem to play an essential role in the formation and/or maintenance of tumors. The functions of these DNA sequences were probed by three complementary approaches.

The accompanying paper (Willmitzer et al., 1982) shows how TL-DNA of octopine tumor lines codes for seven in-

*To whom reprint requests should be sent. dependent and well-defined polyadenylated transcripts of which at least two and probably four have homologous counterparts in nopaline tumors. The introduction of specific mutations in the TL-DNA region of an octopine Ti plasmid, to produce transformed plant cells in which one or more TLDNA derived transcripts would not be expressed, allowed us to assign functions to different transcripts.

A third approach, the specific selection of transcripts by hybridization with cloned T-DNA fragments, followed by in vitro translation, showed that TL-DNA transcript 3 specifies octopine synthase or lysopine dehydrogenase (LpDH) (Schröder et al., 1981a). Several other TL transcripts are translated in mini-cells of Escherichia coli (Schröder et al., 1981b).

If we are to use T-DNA as an experimental gene vector (Hernalsteens et al., 1980; Leemans et al., 1981; Matzke and Chilton, 1981) it is important to identify which functions are responsible for tumorous growth and to discover whether elimination of these onc functions yields "transformed" plant cells able to regenerate to normal fertile plants. The "foreign" genes introduced into these plants via the modified Ti plasmids would have to be stably maintained, expressed, and sexually transmitted. These requirements were recently fulfilled by the production of a normal tobacco plant that contained and expressed the gene for octopine synthase (De Greve et al., submitted; Schell et al., 1981). This plant transmitted this gene sexually as a single dominant Mendelian factor (Otten et al., 1981). The data presented here will be crucial for the development of new Ti plasmid-derived gene vectors with the capacity efficiently to introduce foreign DNA into plant cells without affecting subsequent regeneration of fertile plants.

\section{Results}

\section{General approach}

We have described a method for site-directed mutagenesis of Agrobacterium Ti plasmids, which involves cloning and mutagenesis of chosen $\mathrm{Ti}$ fragments in broad host range vectors ("intermediate vectors") derived from the W-plasmid Sa (Leemans et al., 1981). Site-specific inserts or substitutions in Ti plasmids are produced by exchange of the modified Ti sequence for the wild-type sequence through in vivo recombination between the intermediate vector and a resident $\mathrm{Ti}$ plasmid. By this method, we constructed substitution mutants in the T-region of pTiB6S3 creating a set of deletions of increasing lengths. Table I lists bacterial strains and plasmids, Table II and Figure 1 outline the construction and properties of the intermediate vectors we used.

\section{Construction of mutant Ti plasmids}

Intermediate vectors were transmitted, via the $\mathrm{N}$-type plasmid RN3, into an Agrobacterium recipient strain harboring a Ti plasmid. In vivo recombinants betwen intermediate vector and resident $\mathrm{Ti}$ plasmid were isolated as described by Leemans et al. (1981); see Table III. pGV2219, carrying a deletion without substitution, was constructed as in Figure 2. DNA/DNA hybridizations verified that the T-region of the 
Table I. Bacterial strains and plasmids.

\begin{tabular}{|c|c|c|c|c|c|c|c|c|c|}
\hline & \multicolumn{2}{|c|}{$\begin{array}{l}\text { Relevant } \\
\text { markers }\end{array}$} & \multicolumn{5}{|c|}{ Specifications } & \multicolumn{2}{|l|}{ Reference } \\
\hline \multicolumn{10}{|l|}{ Plasmids } \\
\hline pGV0201 & \multicolumn{2}{|l|}{$\mathrm{Cb}$} & \multicolumn{5}{|c|}{ pBR322 carrying pTiAch5 HindIII fragment 1} & \multicolumn{2}{|c|}{ De Vos et al. (1981) } \\
\hline pGV0153 & \multicolumn{2}{|l|}{$\mathrm{Cb}$} & \multicolumn{5}{|c|}{ pBR322 carrying pTiAch5 BamHI fragment 8} & \multicolumn{2}{|c|}{ De Vos et al. (1981) } \\
\hline pGV98 & \multicolumn{2}{|l|}{$\mathrm{Cb}$} & \multicolumn{5}{|c|}{$\begin{array}{l}\text { derivative of pGV0153, with an EcoRI linker inserted in pTiAch5 } \\
\text { BamHI-I fragment } 8 \text { (denoted as BamHI } 8^{*} \text { ) }\end{array}$} & \multicolumn{2}{|c|}{ Unpublished data } \\
\hline pGV0219 & \multicolumn{2}{|l|}{$\mathrm{Cb}$} & \multicolumn{5}{|c|}{ pBR322 carrying pTiAch5 HindIII fragments $14,18,22$ and 38} & \multicolumn{2}{|c|}{ De Vos et al. 1981) } \\
\hline pGV0507 & \multicolumn{2}{|l|}{$\mathrm{Cb} \mathrm{Tc}$} & \multicolumn{5}{|c|}{ pBR325 carrying pTiAch5 EcoRI fragment 7} & \multicolumn{2}{|c|}{ De Vos et al. (1981) } \\
\hline pGV83 & \multicolumn{2}{|l|}{$\mathrm{Cb}$} & \multicolumn{5}{|c|}{ pGV600 (pBR322 without BamHI-site) carrying pTiAch5 EcoRI fragment 7} & \multicolumn{2}{|l|}{ This work } \\
\hline pGV96 & \multicolumn{2}{|c|}{$\mathrm{Cb} \mathrm{Tc} \mathrm{Km}$} & \multicolumn{5}{|c|}{$\begin{array}{l}\text { pBR325 carrying the } 0.8 \text { Md internal AvalI fragment of } T n 903 \text { modified } \\
\text { into an EcoRI fragment and harboring the } \mathrm{Km}^{\mathrm{R}}\end{array}$} & \multicolumn{2}{|c|}{ Unpublished data } \\
\hline pKC7 & \multicolumn{2}{|c|}{$\mathrm{Cb} \mathrm{Km}$} & & \multicolumn{2}{|c|}{ Rao and Rogers (1979) } \\
\hline pGV1113 & \multicolumn{2}{|c|}{$\mathrm{Sm} \mathrm{Su}$} & \multicolumn{5}{|c|}{$\begin{array}{l}5.6 \mathrm{Md} \text { vector derived from the W-plasmid pGV1106 (Leemans et al., } 1981 \text { ) } \\
\text { by substituting the } 2.5 \mathrm{Md} \text { BglII-BamHI fragment of pGV1106 by the } 2.3 \mathrm{Md} \\
\text { BamHI-4 fragment of } \mathrm{R} 702 \text {, carrying } \mathrm{Sm}^{R} \text { and } \mathrm{Su}^{R}\end{array}$} & Unpublished & data \\
\hline pGV1120 & $\mathrm{Sm} \mathrm{Tc}$ & & $7.4 \mathrm{M}$ & d vector derived from pGV1113 (see & zure 1) & & & Unpublished & data \\
\hline pGV1122 & $\mathrm{Sm} \mathrm{Tc}$ & & $7.2 \mathrm{M}$ & $\mathrm{d}$ vector derived from $\mathrm{pGV} 1120$ by $\mathrm{c}$ & ting a $0.2 \mathrm{Md}$ & BglII-BamHI fr & ment & Unpublished & data \\
\hline pGV1145 & $\mathrm{Sm}$ & & pGV1 & 122 carrying pTiAch5 BamHI fragm & & & & This ẉork & \\
\hline pGV1146 & $\mathrm{Sm}$ & & pGV1 & 122 carrying pTiAch5 BamHI fragm & & & & This work & \\
\hline pTiB6S3 & $\operatorname{tra}^{\mathrm{c}}$ & & pTiB6 & S3 derepressed for autotransfer & & & & Petit et al. 19 & \\
\hline pGV2206 & $\mathrm{Km}^{\mathrm{R}} \mathrm{t}$ & & substit & ution mutant of pTiB6S3 tra $\mathrm{ta}^{\mathrm{c}}$ & & & & Leemans et a & (1981) \\
\hline pGV2208 & $\mathrm{Km}^{\mathrm{R}} \mathrm{t}$ & & substit & ution mutant of pTiBGS 3 tra $^{c}$ & & & & Leemans et a & (1981) \\
\hline Bacterial strai & ains & & & & & & & & \\
\hline A. tumefacier & & & & & & & & & \\
\hline GV3101 & $\mathrm{C} 58 \mathrm{C}$ & $1 \mathrm{Rif}^{\mathrm{R}}$ & & & & & & Van Larebek & et al. (1974) \\
\hline GV3105 & $\mathrm{C} 58 \mathrm{C}$ & 1 Ery ${ }^{R}$ & & & & & & Holsters et al & $(1980)$ \\
\hline Table II. & & & & & Table III. & & & & \\
\hline $\begin{array}{l}\text { Intermediate } \\
\text { vector }\end{array}$ & $\begin{array}{l}\text { Initial } \\
\text { plasmid }\end{array}$ & $\begin{array}{l}\text { Delet } \\
\text { fragn }\end{array}$ & & $\begin{array}{l}\text { Substituted } \\
\text { fragment }\end{array}$ & $\begin{array}{l}\text { Mutant } \\
\text { Ti plasmid }\end{array}$ & $\begin{array}{l}\text { Intermediate } \\
\text { vector }\end{array}$ & $\begin{array}{l}\text { Resident } \\
\text { Ti plasmid }\end{array}$ & $\begin{array}{l}\text { Mutant } T \\
\text { resistant to }\end{array}$ & $\begin{array}{l}\text { plasmid is } \\
\text { sensitive to }\end{array}$ \\
\hline pGV1132 & pGV83 & Baml & $8,30 \mathrm{~b}$ & Bg1II linearized pGV1113 $\left(\mathrm{Sm}^{\mathrm{R}}\right)$ & pGV2210 & pGV1132 & pTiB6S3 tra ${ }^{c}$ & & $\mathrm{Cb}$ \\
\hline pGV1155 & pGV1145 & EcoR & & EcoRI fragment of pGV9 $\left(\mathrm{Km}^{\mathrm{R}}\right)$ & pGV2215 & pGV1155 & pTiB6S3 tra & $\mathrm{Km}$ & Sm \\
\hline pGV1156 & pGV1146 & EcoR & $+\alpha$ & EcoRI fragment of pGV96 $\left(\mathrm{Km}^{\mathrm{R}}\right)$ & pGV2216 & pGV1156 & pTiB6S3 tra ${ }^{c}$ & $\mathrm{Km}$ & Sm \\
\hline pGV1159 & pGV1145 & Bg1II & & -ー- & pGV2217 & pGV1157 & pTiB6S3 tra ${ }^{\mathrm{c}}$ & $\mathrm{Km}$ & $\mathrm{Sm}, \mathrm{Cb}$ \\
\hline pGV1157 & & see $F$ & & & pGV2224 & pGV1132 & pGV2219 & $\mathrm{Sm}$ & $\mathrm{Cb}$ \\
\hline
\end{tabular}

The intermediate vectors were constructed by the in vitro substitution of (an) internal restriction fragment(s) in the initial plasmid by DNA fragments carrying antibiotic resistance markers. In pGV1159 the deleted DNA has not been substituted by foreign DNA. Fragment $\alpha$ in pGV1156 is the $1.30 \mathrm{Md}$ internal EcoRI fragment in pTiAch5 BamHI fragment $8^{*}$, as the consequence of the insertion of an EcoRI DNA linker. Figure 1 shows construction scheme for pGV1157, and Figure 5 shows the extent of the deleted T-region fragments.

mutant Ti plasmids contained the exact deletion or substitution, as constructed in the intermediate vectors (Figure 3).

Properties of primary tumors induced by mutant Ti plasmids

All recombinant strains were inoculated on tobacco, Kalanchoe, tomato and carrot; pGV2206 and pGV2216 were tested only on Petunia. pGV2217 and pGV2224 proved completely avirulent on all plants tested. The other mutants produced transformed cells with phenotypes distinguishable from those of crown gall cells induced by wild-type plasmid. On tobacco, Agrobacterium strains harboring pGV2206 or pGV2215 produced small greenish tumors covered with numerous shoots, whereas the wild-type pTiB6S $3 \operatorname{tra}^{c}$ formed large white unorganized tumors. On Kalanchoe, pTiB6S3 induced large unorganized tumors and some root formation from the tissue surrounding the stem tumors. In contrast,

Mutant Ti plasmids were recovered as recombinants between an intermediate vector and a resident Ti plasmid. Conjugations were performed between the Agrobacterium strains harboring both plasmids and a recipient strain with suitable chromosomal resistance markers. The desired recombinant $\mathrm{Ti}$ plasmids were isolated from colonies which expressed the antibiotic resistance marker substituted in the T-region fragment and had lost the antibiotic resistance marker encoded by the vector part of the intermediate vector. See Figure 5.

strains harboring pGV2206 or pGV2215 induced small tumors on leaves and stems without any observable root formation. The phenomenon of a marked reduction in the size of tumors will be referred to as "attenuation".

The tumors induced by the mutants pGV2216, pGV2219 and pGV2210 on tobacco or Kalanchoe were very similar to those described for pGV2206 or pGV2215. However, it required a 2- or 3-fold longer time (data not shown) to produce tumors of equal size to those produced by pGV2206 or pGV2215, and tumors on the Kalanchoe leaves (with exception of the midrib) occurred only sporadically.

On tomato, the phenotypes of the mutant $\mathrm{Ti}$ plasmids resembled those on tobacco. However, attenuation of tumor from pGV2206-induced tumors, indicating that the deletion was more pronounced, such that degrees of attenuation could 


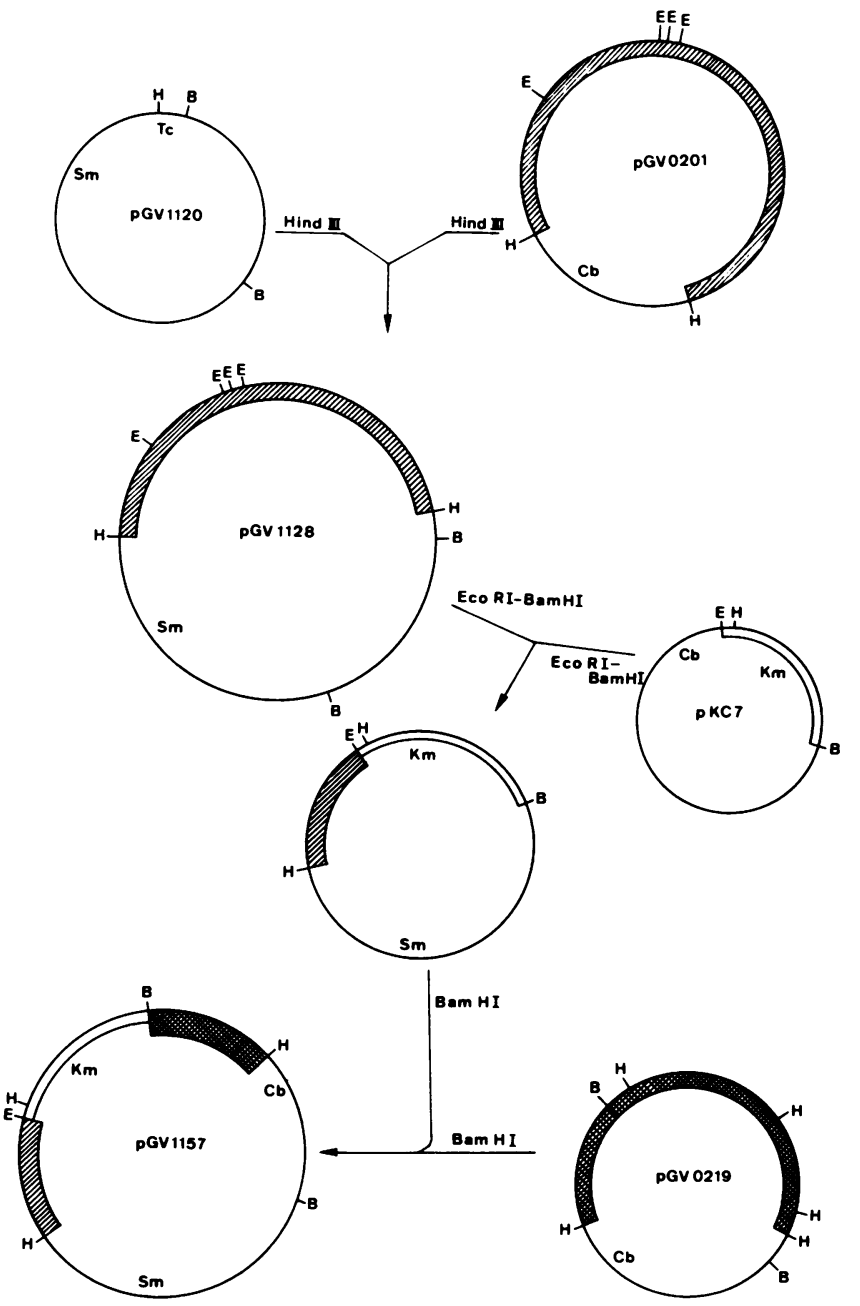

Fig. 1. Intermediate vector pGV1157. HindIII fragment 1 of pTiAch5 was excised from pGV0201 by HindIII digestion and cloned into pGV1120. The recombinant plasmid pGV1128 isolated as a $\mathrm{Sm}^{\mathrm{R}}, \mathrm{Cb}^{\mathrm{S}}, \mathrm{Tc}^{\mathrm{S}}$ clone. A $\mathrm{Sm}^{R} \mathrm{Km}^{\mathrm{R}}$ derivative of pGV1128 was obtained by substitution of internal EcoRI-BamHI and EcoRI fragments by $0.8 \mathrm{Md}$ EcoRI-BamHI fragment of of $\mathrm{pKC7}$ harboring a $\mathrm{Km}^{\mathrm{R}}$ gene. This plasmid was used as a vector for the BamHI fragment of pGV0219 which includes the ampicillin resistance marker of pGV0219. This resulted in the intermediate vector pGV1157, resistant to $\mathrm{Km}, \mathrm{Sm}$, and $\mathrm{Cb}$. Restriction sites on plasmid figures: B, BamHI; E, EcoRI; $\mathrm{H}$, HindIII. Genes coding for antibiotic resistance: $\mathrm{Cb}$, carbenicillin; $\mathrm{Km}$, kanamycin; Sm, streptomycin; Tc, tetracycline.

not be distinguished. On Petunia, pGV2216 was more attenuated than pGV2206, and shoot induction by pGV2216 Petunia tumors was more profuse than by pGV2206 tumors.

On carrot slices without added hormone, wild-type pTiB6S3 tra $^{c}$ induced green tumors within 14 days, most efficiently on the vascular tissue. Mutant plasmids pGV2206, pGV2215, pGV2216, and pGV2219 showed an equal degree of attenuation; tumors appeared only after 4-5 weeks incubation. No organogenesis was observed from tumors induced by mutant or wild-type Ti plasmids, although this carrot variety can be efficiently regenerated from suspension cultures through embryogenesis. Addition of $0.1 \mu \mathrm{g} / \mathrm{ml}$ of 2,4 dichlorophenoxyacetic acid $(2,4 \mathrm{D})$ to the medium on which the carrot slices were placed restored wild-type levels of virulence from the mutant plasmids pGV2206, pGV2215, pGV2216 and pGV2219; no significant proliferation was observed either with the plasmid-free control strain GV3101, or with the avirulent mutants pGV2217 and pGV2224. Octopine synthase activity could be detected in the wound tissue
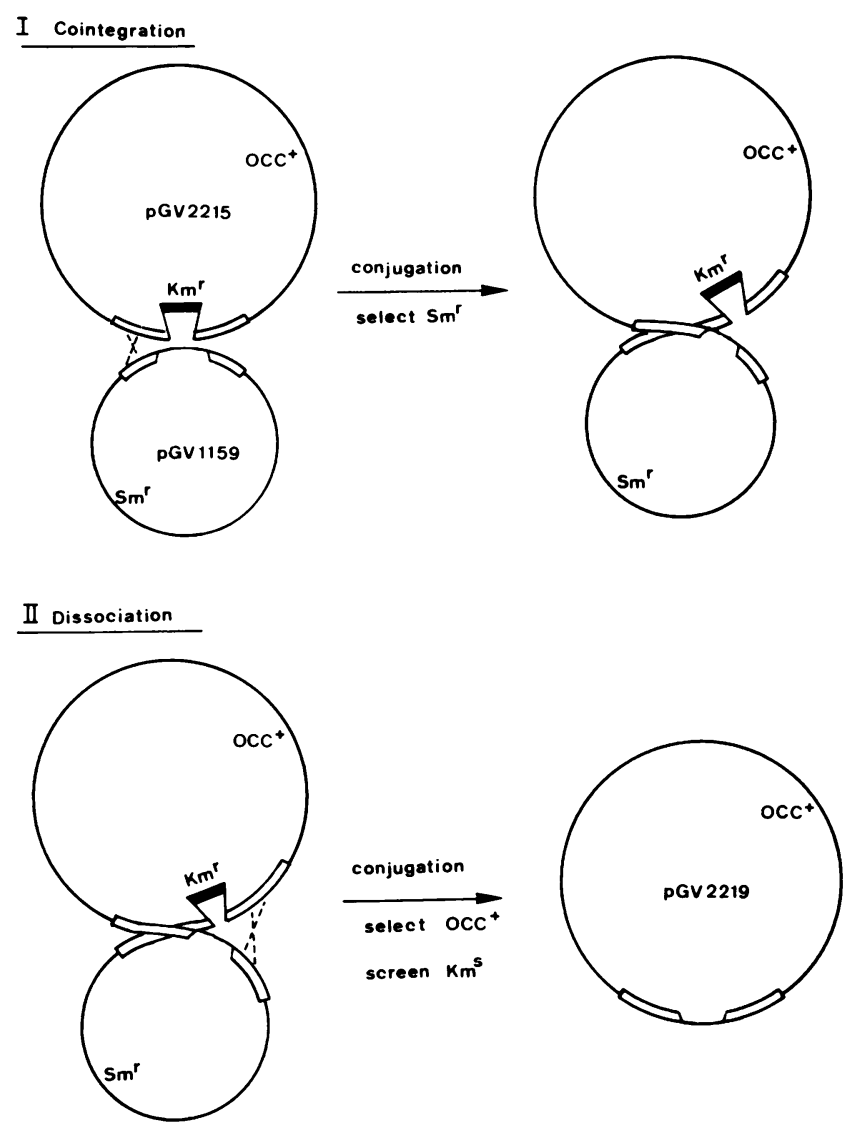

Fig. 2. Isolation of mutant plasmid pGV2219. Both the resident Ti plasmid pGV2215 and the non-conjugative and non-mobilizable intermediate vector pGV1159 carry a T-DNA fragment, mutated in overlapping regions. First, $\infty-$ integration of pGV2215 and pGV1159 was by selecting transfer of the Sm resistance encoded by pGV1159 upon Ti transfer from GV3101(pGV2215) (pGV1157) to GV3105 $\left(10^{-2}\right.$ of the $\mathrm{Ti}$ transfer). The resulting GV3105(pGV2215::pGV1157) was a donor in a second conjugation to GV3101. Ti transconjugants were selected on minimal medium containing octopine as sole nitrogen source. Amongst these, clones were detected at a frequency of $10^{-3}$ which were sensitive to both $\mathrm{Km}$ and $\mathrm{Sm}$. The physical structure of the T-region of such a clone, pGV2219, was verified by DNA/DNA hybridization (Figure 3).

from carrot slices infected with pGV2224 and agropine was present in the wound tissue infected with pGV2217; therefore, the mutated T-DNAs of these avirulent mutants can still be transferred to the plant cell.

Properties of sterile tobacco tissue cultures induced by $\mathbf{m u -}$ tant Ti plasmids

Sterile tumor tissue cultures were obtained from independent tumors induced on sterile tobacco seedlings by the pathogenic $\mathrm{Ti}$ plasmid mutants (pGV2206, pGV2210, pGV2215, pGV2216 and pGV2219). These cultures were initiated on hormone-free MS medium and grew at about the same rate as cultures induced by the wild-type TiB6S3 plasmid. However, their morphology differed significantly from that of wild-type tumors: the mutant tissues were greenish and gave rise to numerous small shoots. Upon separation from the tumor callus, and culture on hormonefree MS medium, these shoots developed in one of two ways:

1) Some shoots formed roots and developed into morphologically normal tobacco plants which grew well in soil. Several hundred morphologically normal plants, obtained from tumors incited with pGV2206, pGV2210, pGV2215, pGV2216, and pGV2219 (at least 50 shoots 


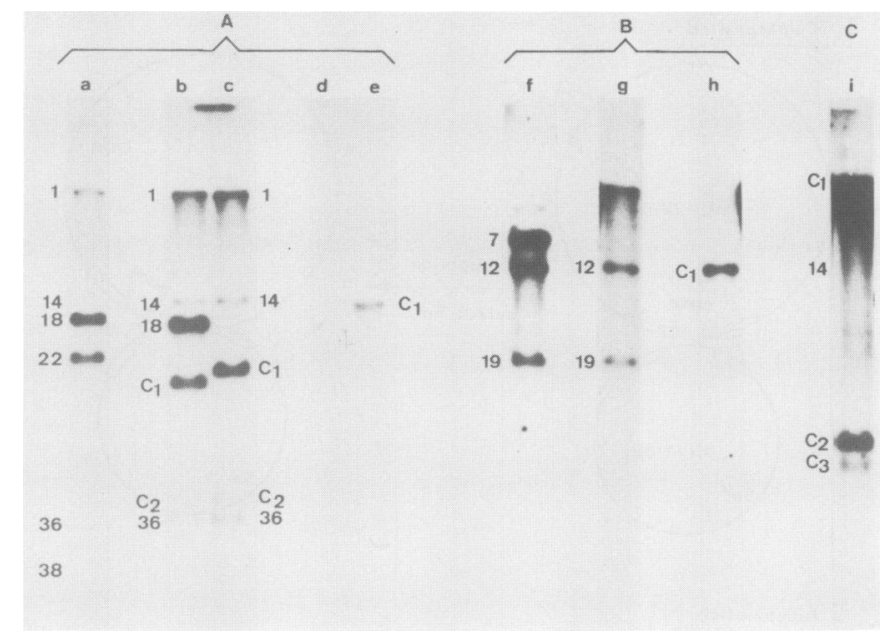

Fig. 3. DNA/DNA hybridizations to verify that, in the mutant pTiB6S3 plasmids, the T-region contained the exact deletion or substitution as in the corresponding intermediate vectors. Filters with restriction patterns of digested total bacterial DNA of strains harboring the mutant plasmids or the wild-type pTiB6S3 $\operatorname{tra}^{\mathrm{c}}$ were hybridized against ${ }^{32} \mathrm{P}$-labeled pGV0153 A, against ${ }^{32}$ P-labeled pGV0201 B, or against a mixture of both probes $\mathbf{C}$. The HindIII digest of pTiB6S3 shows the internal HindIII fragments $1,14,18,22,36$ and 38, lane a. For mutant pGV2215 HindIII fragments 22 and 38 are lost, lane b, and for pGV2216 HindIII fragments 18, 22, and 38 have disappeared, lane c. HindIII fragments 36 and 38 , lane a, and 36 , lane b and c, were clearly visible on the original autoradiograph. In each case, two composite fragments $(\mathrm{Cl}, \mathrm{C2})$ of the correct size appear. pGV2217 does not hybridize with pTiB6S3 BamHI fragment 8, lane d, while this fragment is reduced to $2.0 \mathrm{Md}$ in pGV2219, ane e. Hybridization with the pGV0201 as probe $B$ shows the pTiB6S3 EcoRI fragments 7,12 , and 19, lane f. In pGV2210 EcoRI fragment, 12 and 19 are still present but fragment 7 is, due to the substitution of pGV1113, enlarged to higher molecular weight, lane g. In a HindIII digest of pGV2217, the right end of HindIII fragment 1 only is present and provides the single composite band which hybridizes, lane $h$. Finally, in pGV2224, HindIII fragment 14 is the only internal fragment left; due to the double mutation 3 new composite fragments of the expected size appear, lane i.

from each) were tested for the presence of opines. None contained agropine or mannopine. Octopine was also absent, except in eight out of 54 plants derived from one of the 10 tumor lines induced by pGV2206 (De Greve et al., submitted).

2) Other shoots did not form roots and rapidly proliferated as callus with profuse teratomas. These teratoma-like shoots are tumorous and can revert to a callus-type growth on hormone-free medium. Both their tumorous character and the synthesis of octopine and agropine confirm that these teratoma-like shoots consist of transformed T-DNA containing cells.

\section{$T L-D N A$ derived transcripts in mutant crown gall tissues}

The TL-derived transcripts (see accompanying paper by Willmitzer et al.) in tumor tissues induced by pGV2206 and pGV2216 were compared to those encoded by wild-type TLDNA. pGV2206-induced tumors clearly lack transcripts 1 and 2 whereas normal levels of transcripts 3, 4, 6, 7 and possibly 5 occur (Figure 4a). pGV2216-induced tumors analyzed by a Southern-blotting showed expression only of the DNAregions coding for transcripts 4, 6, and 3 (Figure 4b). Transcript 1 does not hybridize with EcoRI fragment 32 (see accompanying paper by Willmitzer et al.) and it is absent from pGV2206 induced tumors, indicating that the deletion of EcoRI fragment 32 removes a DNA region controlling the expression of transcript 1, presumably its promoter.

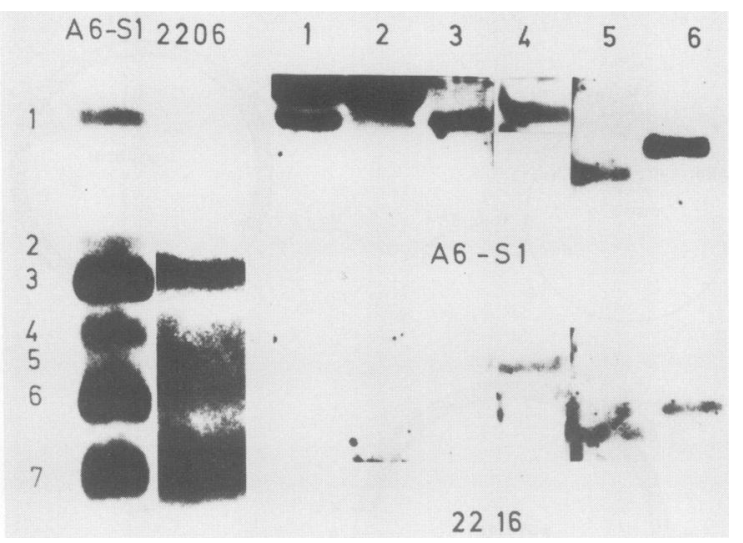

Fig. 4. Analysis of TL-derived transcripts present in tumor lines induced by pGV2206 (4a) and pGV2216 (4b). 4a. Hybridization pattern of total octopine TL-region probes, i.e., BamHI fragment 8 and HindIII fragment 1 of pTiAch5, against Northern blots of poly $\mathrm{A}^{+} \mathrm{RNA}$ isolated from a pGV2206 induced tumor line and from the tumor line A6S1, induced by the wild-type plasmid. Transcripts are numbered 1 to 7 . The films were overexposed to obtain evidence for the presence of transcript 5 . Independent hybridization (data not shown) confirmed the presence of transcripts 4 and 6 in the pGV2206 induced tumor line. $\mathbf{4 b}$. Hybridization of poly $\mathrm{A}^{+} \mathrm{RNA}$, isolated from a pGV2216 induced tumor line (below), against a blot containing T-region fragments specific for one or more transcripts. Above, pattern obtained for the A6S1 control for comparison. For experimental details see accompanying paper, Willmitzer et al. pTiAch5 fragments used as drivers were as follows (the transcript they are coding for is given between brackets): lane 1, HindIII fragment $18(7,5)$ and $22(2)$; lane 2, Smal fragment 16a $(7,5)$ and Smal fragment 17 (5); lane 3, the EcoRI - BamHI fragment common to EcoRI fragment 7 and BamHI fragment 8 (1); lane 4, the EcoRI-KpnI fragment common to EcoRI fragment 7 and KpnI fragment $9(1,4)$; lane 5, the KpnI-SmaI fragment common to $\mathrm{KpnI}$ fragment 5 and Smal fragment $10 \mathrm{c} \mathrm{(6)}$; lane 6, the Smal - EcoRI fragment common to Smal fragment $3 \mathrm{~b}$ and EcoRI fragment 7 (3).
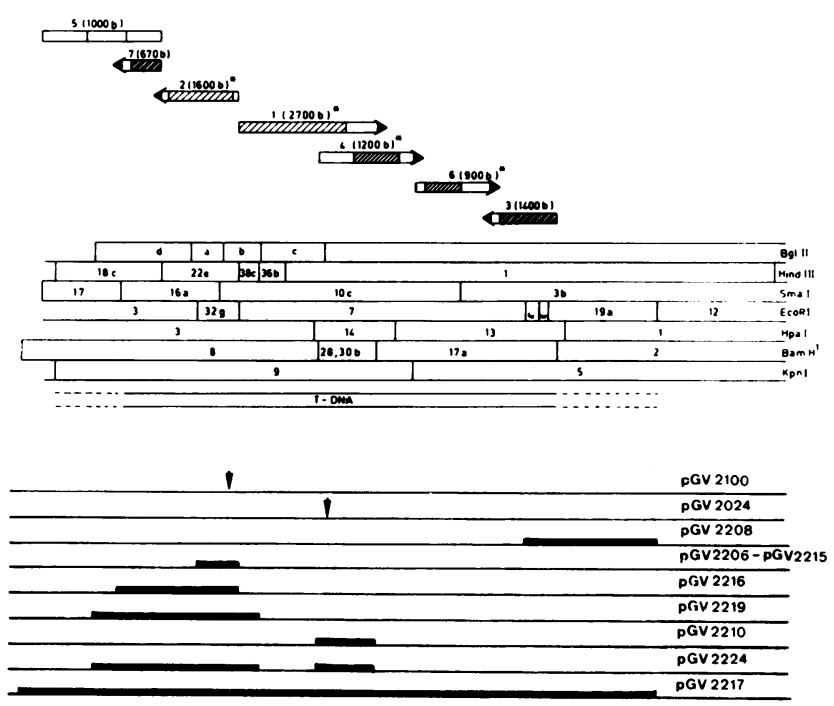

Fig. 5. Schematic representation of the T-region of pTiB6S3 mutant plasmids aligned on the physical map of the T-region. The location, direction, and size of the seven TL-derived transcripts from Willmitzer et al., 1982. The bar denoted as T-DNA represents the extent of TL-DNA in most of the tumor lines studied (De Beuckeleer et al., 1981). The thick lines represent the deleted T-region of the mutant Ti-plasmids. The fragments which substitute most of these deletions are not represented.

\section{Discussion}

We have used site-specific mutations to probe the functions of T-DNA transcripts and to produce Ti-plasmid mutants capable of transferring modified T-DNA sequences from which the tumor-controlling genes were eliminated. In octopine crown galls seven independent polyadenylated 
transcripts are derived from TL-DNA. At least two and probably four of these transcripts have homologous counterparts in nopaline tumors (see Willmitzer et al., accompanying paper).

Methods have been developed to introduce site-specific insertions or substitutions in Ti plasmids, based on the use of so-called "intermediate vectors" (Leemans et al., 1981). To construct pGV2219, a Ti mutant carrying a deletion without substitution, we extended this method to allow the introduction of any non-selectable DNA in Ti plasmids by the isolation, in two steps, of recombinants between a Ti plasmid that already carries an antibiotic resistance marker in its T-region and an intermediate vector. The loss of that antibiotic resistance allows screening for the introduction in the $\mathrm{Ti}$ plasmid of the non-selectable T-region fragment, present on the intermediate vector (see also Figure 2).

These methods simplified the contruction of a series of mutant $\mathrm{Ti}$ plasmids carrying well-defined deletions in the TLregion which eliminate specifically one or more of the seven known transcripts. Figure 5 shows the structure of such mutants.

From the properties of tissues derived from plants infected by Agrobacterium strains carrying these mutant Ti plasmids and analysis of the TL-DNA derived transcripts in some of the mutant crown gall lines, we conclude:

1) T-DNA transfer and tumor growth are controlled by different and independently acting functions. None of the TL-DNA transcripts appear to be essential for T-DNA transfer. Indeed, T-DNA transfer occurred with all the mutants tested, including those that were unable to induce tumorous growth. With the latter, T-DNA transfer was inferred from the induction of opine synthesis in tissues infected with agrobacteria carrying Ti plasmids from which a larger part (pGV2224) or the whole of the TL-region (pGV2217) was deleted. Assuming that opine synthesis in plant tissue can occur only if the relevant genes are introduced as part of a T-DNA transfer, these results confirm that none of the transcripts of TL-DNA are essential for T-DNA transfer. That transcript 3, which codes for octopine synthase (see accompanying paper by Willmitzer $e t$ $a l$.), is not involved in TL-DNA transfer is confirmed since mutants, such as pGV2208 (Leemans et al., 1981) were able to transfer TL-DNA and form tumors from which both LpDH activity and transcript 3 were absent (unpublished data). Similarly, Tn5 insertion mutants (Garfinkel et al., 1981) with locations expected to inactivate transcript 3 (such as 354) or transcript 6 (such as 346), could transfer T-DNA.

2) Most, if not all, of the transcripts must be initiated from independent promoters on TL-DNA. Indeed, expression of $5^{\prime}$ distal transcripts, such as 4 and 6, does not depend on transcription of the $5^{\prime}$ - proximal transcript 1 (see transcription of TL-DNA in tumors induced by pGV2206). Similarly, the appearance of transcript 7 is not affected by inactivation of transcript 2 , in tumors induced either with pGV2100 (De Greve et al., submitted) or with pGV2206.

3) The gene(s) involved in the synthesis of agropine cannot be encoded by TL-DNA since agropine occurs in wound tissue of carrot slices infected with pGV2217, which lacks the entire TL-region. This is a first indication, and further evidence will be presented elsewhere, of the location of the genes involved in agropine synthesis on the TR-region.
4) Four, and possibly five, of the TL-DNA transcripts act by suppressing organ development. This conclusion summarizes the four following points for which the evidence will be presented below: (i) shoot and root formation are suppressed by different transcripts; (ii) transcripts 1, 2 and 4 probably produce growth hormone-like substances because they suppress organ development from both transformed and T-DNA negative cells; (iii) transcripts 5 and 6 , in combination with transcripts 1,2 , and 4 , appear to suppress development only in the cells in which they are formed; and (iv) a combination of two transcripts, such as 4 and 6 , is sufficient to allow hormone-independent proliferation of transformed cells.

These conclusions rest on the following observations: sterile tobacco tumors, incited by shoot-inducing mutant pGV2100 contain normal amounts of transcripts 5, 7, 4, 6 and 3 , a reduced level of transcript 1 , and are devoid of transcript 2 (unpublished results). pGV2024 (De Greve et al., 1981) a Tn7 insertion which should eliminate transcript 1 (cf Figure 5) also results in a high-frequency of shoot induction. Tobacco tumors induced by shoot-inducing mutant pGV2206 are devoid of transcripts 1 and 2, and have normal amounts of the other TL transcripts. Shoots formed on the tumors appeared to be of three types:

1) The majority developed into normal rooting plants when separated from the tumors and did not contain any measurable T-DNA activity, since they did not synthesize either octopine or nopaline. Most probably, these shoots were formed either by untransformed cells, present in the tumor tissue or by cells from which T-DNA was largely or totally deleted.

2) Some of the sterile tumor tissues induced by pGV2206 produced teratoma-like shoots, that were unable to form roots and in which opine synthesis was detected. Such opinepositive teratoma-like shoots were more frequently observed on tumors induced by pGV2216. These tumors are devoid of transcripts $5,7,1$, and 2 , but have normal amounts of transcripts 4,6 , and 3 . It is therefore likely that low levels, or absence, of transcript 5 , together with the absence of transcripts 1 and 2, allow transformed cells to grow as teratoma. The observation that nopaline tumor tissue, induced with a mutant pTiC58 plasmid carrying a deletion in the T-regions homologous to transcripts 2 and 5 , also grew as nopaline-positive teratoma (unpublished data) strengthens this conclusion. That Tn5 insertions in the TL-region of transcript 5 have no observable effect on the morphology of induced tumors (Garfinkel et al., 1981), indicates that the absence of transcript 5 alone does not allow the transformed cells to grow as teratoma-like shoots.

3) Exceptionally, octopine-positive shoots formed roots when separated from the tumor. These plants contained T-DNA, expressed transcript 3, and contained octopine synthase (unpublished results). The T-DNA of these plants behaved as a single dominant Mendelian factor in sexual crosses (Otten et al., 1981).

Transcript 4 appears specifically to prevent root formation both by transformed and untransformed cells, since Tn 5 insertions (Garfinkel et al., 1981) and a Tn904 insertion (Ooms et al., 1981) in the TL-region coding for transcript 4 induce tumors from which roots develop. Nopaline crown galls express a transcript which is homologous and equal in size to 
transcript 4 (Willmitzer et al., accompanying paper). Insertion mutations in the nopaline T-region coding for the equivalent of transcript 4 also lead to root formation (unpublished data). These roots appeared to have developed from untransformed cells or from cells in which the T-DNA was deleted, since no octopine (Ooms et al., 1981) or nopaline could be detected. The fact that mutant pGV2210, which should eliminate transcripts 1 and 4, forms tumors from which untransformed shoots originated and from which roots may proliferate only after a prolonged growth period, if at all, confirms that transcript 1 suppresses shoot formation. Thus, root formation on tobacco tumors induced by $\mathrm{Ti}$ mutants with inserts in the T-region coding for transcript 4 , is more pronounced than on tumors induced by mutants with a deletion of the region coding for transcripts 1 and 4 . At present, the implication of this observation is unclear.

The combination of two of the TL-DNA derived transcripts is sufficient to allow growth hormone-independent proliferation of transformed cells as mutant pGV2216 and pGV2219 can readily form teratoma-like tumors. Such tumors were found to contain transcripts 4,6 , and 3 .

All of these observations could be formally explained by postulating that transcripts 1 and 2 have an auxin-like function, whereas transcript 4 has a cytokinin-like function. Indeed, these transcripts appear to code for growth-controlling elements that are transmitted from transformed to T-DNA negative cells. Transcripts 1 and 2 suppress shoot formation as does auxin externally supplied to normal tobacco calli. Transcript 4 suppresses root formation as do cytokinins externally supplied to tobacco shoots. The (unknown) products of transcripts 5 and 6 appear to play an additional role only in the cells in which they are produced. We cannot yet assign any specific function to transcript 7 , which together with transcript 3 was found to be specific for octopine crown gall. Transcript 3 has been identified as coding for the octopine synthesizing LpDH.

\section{Materials and methods}

Bacterial strains and plasmids

These are listed in Table I.

\section{Tumor induction}

Inoculations were performed on Kalanchoe daigremontiana stems and leaves and on decapitated plants of tobacco (Nicotiana tabacum cv. Wisconsin 38), diploid Petunia hybrida MD1 (Mitchell et al., 1980), and tomato (Lycopersicon esculentum cv. Marmande). Plants were grown in vermiculite under culture room conditions $\left(70 \%\right.$ humidity, $24^{\circ} \mathrm{C}, 16 \mathrm{~h} /$ day illumination at 12000 lux).

Carrots (Daucus carota cv. Juwarot) were disinfected for $20 \mathrm{~min}$ in $\mathbf{8 0 \%}$ commercial bleach and $20 \%$ laboratory detergent ("Decontamin") and subsequently rinsed 5 times with sterile water; 3-4 mm slices were placed in 5-cm Petri dishes on a medium containing the salts of the Murashige and Skoog medium and 0.7\% agar (Murashige and Skoog, 1962). Inoculation was with $20 \mu \mathrm{l}$ overnight bacterial culture, resuspended in $0.01 \mathrm{M} \mathrm{MgSO}_{4}$. Some inoculations were on carrot slices in a Murashige and Skoog medium supplemented with $0.1 \mu \mathrm{g} / \mathrm{ml} 2,4 \mathrm{D}$. The plates were sealed and incubated.

Analysis of $T L$-derived transcripts

TL-derived transcripts were detected in sterile tumor tissues as described by Willmitzer et al. (accompanying paper).

Other methods

Media and culture conditions, plasmid isolation, DNA analysis, genetic analysis, induction and culture of tobacco crown gall tumors and detection of octopine and agropine, were as described previously (Leemans et al., 1981).

\section{Acknowledgements}

We thank Ms. L. Thia Toong and Ms. F. De Boeck for excellent technical assistance, Ms. M. De Cock for typing the manuscript, and A. Verstraete for photographic work. This research was supported by grants from the "Fonds voor Kollektief Fundamenteel Onderzoek" (F.K.F.O. 2007.77) and from the Services of the Prime Minister ("Onderling Overlegde Akties"/12052179). J.P.H. is a research associate of the National Fund for Scientific Research (Belgium).

\section{References}

Chilton,M.-D., Drummond,M.H., Merlo,D.J., and Sciaky,D. (1978) Nature, 275, 147-149.

De Beuckeleer,M., Lemmers,M., De Vos,G., Willmitzer,L., Van Montagu, M., and Schell,J. (1981) Mol. Gen. Genet., 183, 283-288.

Depicker,A., Van Montagu,M., and Schell,J. (1978) Nature, 275, 150-153.

De Vos,G., De Beuckeleer,M., Van Montagu,M., and Schell,J. (1981) Plasmid, 6, 249-253.

Engler,G., Depicker,A., Maenhaut,R., Villarroel-Mandiola,R., Van Montagu,M., and Schell,J. (1981) J. Mol. Biol., 152, 183-208.

Garfinkel,D.J., Simpson,R.B., Ream,L.W., White,F.F., Gordon,M.P., and Nester,E.W. (1981) Cell, 27, 143-153.

Hernalsteens,J.P., Van Vliet,F., De Beuckeleer,M., Depicker,A., Engler,G., Lemmers,M., Holsters,M., Van Montagu,M., and Schell, J. (1980) Nature, 287, 654-656.

Holsters,M., Silva,B., Van Vliet,F., Genetello,C., De Block,M., Dhease,P., Depicker,A., Inzé,D., Engler,G., Villarroel,R., Van Montagu,M., and Schell,J. (1980) Plasmid, 3, 212-230.

Leemans,J., Shaw,C., Deblaere,R., De Greve,H., Hernalsteens,J.P., Maes, M., Van Montagu,M., and Schell,J. (1981) J. Mol. Appl. Genet., 1, 149-164.

Lemmers,M., De Beuckeleer,M., Holsters,M., Zambryski,P., Depicker,A., Hernalsteens,J.P., Van Montagu,M., and Schell,J. (1980) J. Mol. Biol., 144, 353-376.

Matzke,A.J.M., and Chilton,M.-D. (1981) J. Mol. Appl. Genet., 1, 39-49.

Mitchell,A.D., Hauson,M.R., Skvirsky,R.C., and Ausubel,F.M. (1980) Z. Pflanzenphysiol., 100, 131-146.

Murashige,T., and Skoog,S. (1962) Physiol. Plant., 15, 473-497.

Ooms,G., Hooykaas,P.J., Moleman,G., and Schilperoort,R.A. (1981) Gene, 14, 33-50.

Otten,L., De Greve,H., Hernalsteens,J.P., Van Montagu,M., Schieder,O., Straub,J., and Schell,J. (1981) Mol. Gen. Genet., 183, 209-213.

Petit,A., Tempé,J., Kerr,A., Holsters,M., Van Montagu,M., and Schell,J. (1978) Nature, 271, 570-572.

Rao,R.N., and Rogers,S.G. (1979) Gene, 7, 79-82.

Schell,J., Van Montagu,M., Holsters,M., Hernalsteens,J.P., Leemans,J., De Greve,H., Willmitzer,L., Otten,L., Schröder,J., and Shaw,C. (1981) in Brown,D., and Fox,C.F. (eds.), Developmental Biology using Purified Genes, ICN-UCLA Symposia on Molecular and Cellular Biology, XXIII, Academic Press, NY, pp. 557-575.

Schröder,J., Schröder,G., Huisman,H., Schilperoort,R.A., and Schell,J. (1981a) FEBS Lett., 129, 166-168.

Schröder,J., Hillebrandt,A., Klipp,W., and Pühler,A. (1981b) Nucleic Acids Res., 9, 5187-5202.

Thomashow,M.F., Nutter,R., Montoya,A.L., Gordon,M.P., and Nester, E.W. (1980a) Cell, 19, 729-739.

Thomashow,M.F., Nutter,R., Postle,K., Chilton,M.-D., Blattner,F.R., Powell,A., Gordon,M.P., and Nester,E.W. (1980b) Proc. Natl. Acad. Sci. USA, 77, 6448-6452.

Van Larebeke,N., Engler,G., Holsters,M., Van den Elsacker,S., Zaenen,I., Schilperoort,R.A., and Schell,J. (1974) Nature, 252, 169-170.

Willmitzer,L., Simons,G., and Schell,J. (1982) EMBO J., 1, 139-146.

Yadav,N.S., Postle,K., Saiki,R.K., Thomashow,M.F., and Chilton,M.-D. (1980) Nature, 287, 458-461.

Zambryski,P., Holsters,M., Kruger,K., Depicker,A., Schell,J., Van Montagu,M., and Goodman,H.M. (1980) Science (Wash.), 209, 1385-1391. 